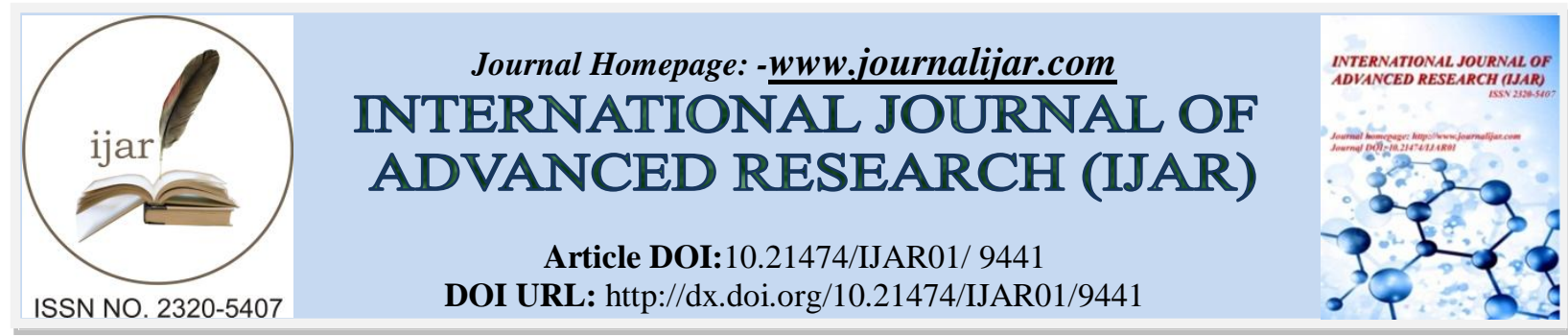

RESEARCH ARTICLE

\title{
ASSESSMENT OF READINESS TO HANDLE FIRE CHALLENGES IN A TERTIARY CARE TEACHING INSTITUTE.
}

\author{
Girish Deshmukh ${ }^{1}$, Ashutosh Sharma ${ }^{2}$, Saroj Kumar Patnaik ${ }^{3}$ and Saurabh Singh ${ }^{4}$. \\ 1. Junior Resident, Dept of Hosp Adm, Armed Forces Medical College, Pune. \\ 2. Prof \& HoD, Dept of Hosp Adm, Armed Forces Medical College, Pune. \\ 3. Assoc Prof, Dept of Hosp Adm, Armed Forces Medical College, Pune. \\ 4. Senior Resident, Dept of Hosp Adm, SGPGIMS, Lucknow.
}

\section{Manuscript Info}

.........................

Manuscript History

Received: 24 May 2019

Final Accepted: 26 June 2019

Published: July 2019

Key words: -

Fire challenges, Gap analysis, Tertiary care teaching institute, healthcare

\section{Abstract}

Rationale: Fire incidents in hospitals in the recent past have brought to fore the necessity of continuous efforts for fire prevention in all Healthcare organizations (HCOs). The recent devastating fire accidents in country highlighted lacunae in hospitals and were harsh learning experiences both for administrators as well as fire safety regulators. In today's world of advanced technology, "nothing is safe" and the challenge of handling disasters caused by job related accidents always exists. Therefore, preparedness of HCOs, for probable accidents and providing safety for patients, staff and materials is vital.

Objectives. The study aimed to carry out fire audit i.e. examination of premises as well as conducted relevant document review to ascertain how the premises are being managed regarding fire safety. The study also undertook assessment of level of fire awareness amongst occupiers, identified gaps and made recommendations. Recommendations were made to make the organization compliant with the fire safety standards as per National Building Code 2016.

Methodology: An observational study by carrying out audit of infrastructure, equipment, policies for preparedness in preventing/fighting fire as well as awareness amongst various categories of personnel was assessed. Structured questionnaire was given to stake-holders to gather factual information from all areas, which was later analyzed through Focused Group Discussions. The audit included five critical components of Fire maintenance, Staff training, Fire prevention, Fire alarm and Fire evacuation plan (last 2 included under Fire action plan).

Results: The overall fire safety compliance was found to be $60.42 \%$. Fire prevention and Fire maintenance compliance percentages were $83.8 \%$ and $67.92 \%$ respectively. The critical non-compliant factors identified were staff training and Fire action plan. Level of fireawareness of the study population was associated with educational level and job tenure.

Conclusion: Fire safety in healthcare is a sensitive topic as the very existence of healthcare facilities controlled by government agencies suggests that nation, through government, has taken responsibility to 
care for people who are ill in some way. If patients or staff members are harmed by fire accidents, then it is a direct reflection on quality of management of total healthcare system. The study provides insight into identifying the critical factors in order to help minimize potential adverse effects whilst at the same time provides recommendations for integration of organizational requirements with NBC 2016 guidelines.

Copy Right, IJAR, 2019. All rights reserved.

\section{Introduction:-}

Nowadays, more attention is being paid to different aspects of occupational safety. ${ }^{[1]}$ In health system, safety is defined as a set of security measures used to protect the physical assets, staff and clients and also reduce the possibility of damage; of course, safety cannot eliminate all the risks. ${ }^{[2]}$ The first reason for paying attention to safety in hospitals is the moral responsibility. ${ }^{[3]}$ In fact, all the organizations, especially those which provide emergency services, are committed to create a safe environment for both the staff and the clients. ${ }^{[4]}$ The second reason for paying attention to safety is the legal responsibility. Observing safety considerations in different areas of institute can lead to reduction of risks and potential complaints. ${ }^{[1]}$

Manpower is a fundamental and important resource for every organization and paying heed to this resource is critical for any organizational success. ${ }^{[5]}$ Staff in any organization are exposed to occupational hazards and are susceptible to several job-related diseases. ${ }^{[6]}$ Observing safety principles is one of the important tasks of administrators.

Fire is a life-threatening event for any organization, which can inflict both financial damage as well as human resource injuries. However, it is seen that fire safety is not in the day to day priority of most individuals and organizations. Habits, such as working casually or in an unsafe manner are usually the result of lack of knowledge. Thus, job training with an emphasis on safety aspects is very effective in driving employee behavior, preventing safety related accidents, and also eliciting appropriate response in such situations. Hence the first step in fire prevention in any organization is training and sensitization related to various safety aspects, including fire prevention. Owing to the importance of fire and its impact on the functioning and image of healthcare organizations, it was decided to assess the fire safety status of a tertiary care teaching institute and make recommendations, if any.

\section{Materials and Methods: -}

Structured questionnaire was given to stake-holders to assess areas for collecting factual information which was later scrutinized through Focused Group Discussions. Since the fire-safety audit is meant to measure fire risk impact on levels of fire safety in individual buildings, it became essential to carry out risk profiling of existing buildings. The assessment included five critical components like Fire maintenance, staff training, Fire prevention, Fire alarm and Fire evacuation plans. (last two included under Fire action plan).

The institute spread over 107 acres has multiple stand-alone buildings. In order to evaluate the fire safety status, the institute was divided into 14 sub-sectors based on their locations. (Table I) The questionnaire containing fifty-one questions was evaluated under five components as discussed above to make this study easier for analysis. All the sub-sectors were audited in the similar manner to maintain consistency in collecting data. All items of the checklist were observed by the researchers. The items were assessed to be either present/provided (yes) or not present/provided (no). The item was, then, scored 1 if it were present/provided (yes) and 0 if it were not present/provided (no). The total safety score was calculated by adding all score of items in the checklist. ${ }^{[7]}$

The questionnaire also included questions in order to evaluate the level of fire awareness. Based on the inputs, only high-risk buildings i.e. densely populated, occupied $24 \times 7$ or with high density of biomedical and electrical equipment were physically inspected. Aspects seen were factors like number and location of fire points, hazmat storage, signages and information display.

A questionnaire survey was chosen in this research because it enabled gathering of more quantitative information. Before the respondents were asked to complete the survey, the stakeholders were briefed on the purpose of research. In Section I the questions solicited about fire equipment maintenance i.e. adequacy, accessibility, siting of the 
equipment and their log books. Section II collected information on the fire prevention checklist and predisposing or potential factors. Section III obtained information on training, display of fire orders and record of mock drills while Section IV dealt with adequacy, location and operability of fire detection devices. Section V obtained information relating to modes of evacuation and signposting of layout.

Emphasis was given on identifying subsectors having equipment generating heat and materials which are combustible under right circumstances at relatively lower temperatures as the fuel for fire does not have to be recognized fuel in the sense of petrol or gas. The factors like compressed air, oxygen cylinders enhancing the naturally present oxygen in order to aid combustion were also identified.

The respondents in the research were given questionnaires with time provided for self-administration at convenient locations. In brief, the data was collected through a self-conducted fire safety audit and the use of a selfadministered questionnaire.

\section{Result: -}

An audit was carried out of all the 14 subsectors as per the NBC 2016 Norms. The subsectors were either a block having many departments or a group of many standalone buildings. Few buildings were occupied $24 \times 7$ which included the hostels and accommodation for staff. The response on fire safety status of buildings which were compliant were marked $\mathrm{Y}$ and those non-compliant were marked $\mathrm{N}$. There were few subsectors which along with a $\mathrm{Y}$ or $\mathrm{N}$ had a comment to add in the remark's column provided in the questionnaire. Those remarks were also incorporated in the results. The score of each $\mathrm{Y}$ and $\mathrm{N}$ was then converted into percentage. The results thus obtained are presented in Table II.

The overall fire safety compliance was found to be 60.42 percent. It was found that subsectors $\mathrm{A}, \mathrm{C}$ and $\mathrm{F}$ are 83 , 76.9 and $76.2 \%$ compliant respectively (Figure I) as these sub-sectors had inflammatory and hazardous materials which followed the fire safety standards better than other sub-sectors. Few subsectors B, H and MB were < $45 \%$ compliant. (Table III) The reason for this could be attributed to less perception of fire threats by stake holders. The compliance of Fire maintenance and Fire prevention were $83.8 \%$ and $67.9 \%$ respectively whereas Fire action plan (including evacuation and alarm system) and staff training compliance were $46.04 \%$ and $43.94 \%$ respectively. (Figure II) The factor wise subsector compliance is described in Figure III.

\begin{tabular}{|c|c|c|c|}
\hline Sr No & Sub Sector & Areas covered & Remarks \\
\hline 1 & $\mathrm{~A}$ & $\begin{array}{l}\begin{array}{l}\text { Dental Surgery, Electrical Substation, Animal House, Living } \\
\text { accommodation }\end{array} \\
\end{array}$ & \\
\hline 2 & B & $\begin{array}{l}\text { Library, Psychiatry, Forensic Medicine, Obstetrics \& Gynae, Paediatrics, } \\
\text { ENT, Orthopaedics depts, DNA Lab, Establishment office }\end{array}$ & \\
\hline 3 & $\mathrm{C}$ & $\begin{array}{l}\text { Laboratory Science block, Dermatology dept, Lecture Halls and } \\
\text { Auditorium }\end{array}$ & \\
\hline 4 & $\mathrm{D}$ & Transport section, Patients Inspection room, Mandir, Warden room & \\
\hline 5 & E & Living accommodation of staff & \\
\hline 6 & $\mathrm{~F}$ & $\begin{array}{l}\text { LPG Stores, Gas plant, Pump house, Mechanical Laundry, Ration and } \\
\text { Fuel stores, Dhobi ghat, Medical Stores, Masjid }\end{array}$ & \\
\hline 7 & $\mathrm{G}$ & Hostel (multiple stand-alone buildings), Dining mess & \\
\hline 8 & $\mathrm{H}$ & Single living old and new accommodation, & \\
\hline 9 & $\mathrm{~J}$ & Nursing College, Nursing dining mess & \\
\hline 10 & K & $\begin{array}{l}\text { Pharmacology, Physiology dept, Principal office, Accounts \& Admission } \\
\text { section }\end{array}$ & \\
\hline 11 & MB & Administrative block, paramedical and training wing, guest rooms & \\
\hline 12 & $\begin{array}{l}\text { Misc and } \\
\text { School }\end{array}$ & Various schools and Family welfare centre (Miscellaneous buildings) & \\
\hline 13 & OR & All staff of institute including single and married accommodation & \\
\hline 14 & Radio & Radio diagnostic department including MRI and Patient waiting area & \\
\hline
\end{tabular}

Table I: - Various Sub-sectors 
Table II:-(Fire Safety Measures) Subsector Compliance: Factor wise

\begin{tabular}{|c|c|c|c|c|}
\hline Inspected subsectors & Inspected plan & Compliant level (\%) & Non-compliant level (\%) & Total $(\%)$ \\
\hline \multirow[t]{4}{*}{ Subsector A } & Fire maintenance plan & 67.19 & 32.81 & 100 \\
\hline & Fire prevention plan & 95.00 & 05.00 & 100 \\
\hline & Staff training plan & 100.00 & 00.00 & 100 \\
\hline & Fire action plan & 70.00 & 30.00 & 100 \\
\hline \multirow[t]{4}{*}{ Subsector B } & Fire maintenance plan & 36.36 & 63.64 & 100 \\
\hline & Fire prevention plan & 86.36 & 13.64 & 100 \\
\hline & Staff training plan & 16.36 & 83.64 & 100 \\
\hline & Fire action plan & 36.36 & 63.64 & 100 \\
\hline \multirow[t]{4}{*}{ Subsector C } & Fire maintenance plan & 79.86 & 20.14 & 100 \\
\hline & Fire prevention plan & 90.00 & 10.00 & 100 \\
\hline & Staff training plan & 75.56 & 24.44 & 100 \\
\hline & Fire action plan & 62.28 & 37.78 & 100 \\
\hline \multirow[t]{4}{*}{ Subsector D } & Fire maintenance plan & 55.73 & 44.27 & 100 \\
\hline & Fire prevention plan & 88.33 & 11.67 & 100 \\
\hline & Staff training plan & 40.00 & 60.00 & 100 \\
\hline & Fire action plan & 50.42 & 49.58 & 100 \\
\hline \multirow[t]{4}{*}{ Subsector E } & Fire maintenance plan & 75.00 & 25.00 & 100 \\
\hline & Fire prevention plan & 70.00 & 30.00 & 100 \\
\hline & Staff training plan & 80.00 & 20.00 & 100 \\
\hline & Fire action plan & 65.00 & 35.00 & 100 \\
\hline \multirow[t]{4}{*}{ Subsector F } & Fire maintenance plan & 78.68 & 21.32 & 100 \\
\hline & Fire prevention plan & 92.36 & 07.64 & 100 \\
\hline & Staff training plan & 68.24 & 31.76 & 100 \\
\hline & Fire action plan & 65.88 & 34.12 & 100 \\
\hline \multirow[t]{4}{*}{ Subsector G } & Fire maintenance plan & 85.42 & 14.58 & 100 \\
\hline & Fire prevention plan & 90.00 & 10.00 & 100 \\
\hline & Staff training plan & 83.24 & 16.66 & 100 \\
\hline & Fire action plan & 12.97 & 87.03 & 100 \\
\hline \multirow[t]{4}{*}{ Subsector H } & Fire maintenance plan & 84.37 & 15.63 & 100 \\
\hline & Fire prevention plan & 80.00 & 20.00 & 100 \\
\hline & Staff training plan & 00.00 & 100.00 & 100 \\
\hline & Fire action plan & 16.66 & 83.34 & 100 \\
\hline \multirow[t]{4}{*}{ Subsector J } & Fire maintenance plan & 84.38 & 15.62 & 100 \\
\hline & Fire prevention plan & 90.00 & 10.00 & 100 \\
\hline & Staff training plan & 00.00 & 100.00 & 100 \\
\hline & Fire action plan & 40.00 & 60.00 & 100 \\
\hline \multirow[t]{4}{*}{ Subsector K } & Fire maintenance plan & 61.72 & 38.28 & 100 \\
\hline & Fire prevention plan & 75.00 & 25.00 & 100 \\
\hline & Staff training plan & 55.00 & 45.00 & 100 \\
\hline & Fire action plan & 40.00 & 60.00 & 100 \\
\hline \multirow[t]{4}{*}{ Subsector MB } & Fire maintenance plan & 52.35 & 47.65 & 100 \\
\hline & Fire prevention plan & 76.25 & 23.75 & 100 \\
\hline & Staff training plan & 05.00 & 95.00 & 100 \\
\hline & Fire action plan & 42.50 & 57.50 & 100 \\
\hline \multicolumn{2}{|c|}{ Subsector Misc \& Sch Fire maintenance plan } & 50.00 & 50.00 & 100 \\
\hline \multicolumn{2}{|c|}{ Fire prevention plan } & 90.00 & 10.00 & 100 \\
\hline & Staff training plan & 05.00 & 95.00 & 100 \\
\hline & Fire action plan & 42.50 & 57.50 & 100 \\
\hline \multirow[t]{4}{*}{ Subsector OR } & Fire maintenance plan & 87.75 & 12.50 & 100 \\
\hline & Fire prevention plan & 80.00 & 20.00 & 100 \\
\hline & Staff training plan & 40.00 & 60.00 & 100 \\
\hline & Fire action plan & 60.00 & 40.00 & 100 \\
\hline
\end{tabular}




\begin{tabular}{|llccc|}
\hline Subsector Radio & Fire maintenance plan & 52.08 & 47.92 & 100 \\
\hline & Fire prevention plan & 70.00 & 30.00 & 100 \\
\hline & Staff training plan & 46.66 & 53.34 & 100 \\
\hline & Fire action plan & 40.00 & 60.00 & 100 \\
\hline Note: The entire college was covered under these various subsectors & & \\
\hline
\end{tabular}

Figure I: -Subsector wise compliance

\section{Compliance: Subsectorwise}

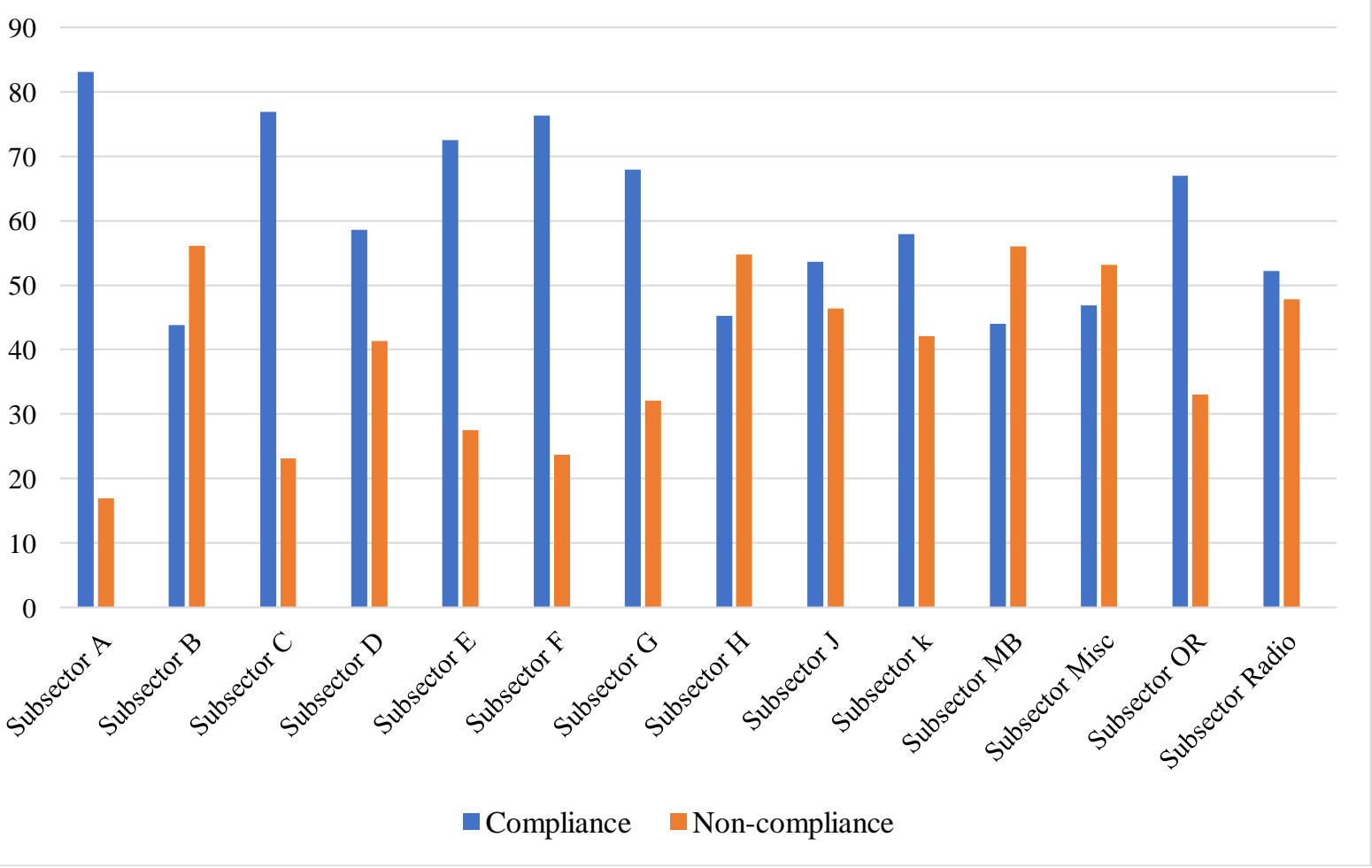

Table III: -Compliance rate of various subsectors: A summary

\begin{tabular}{|lccc|}
\hline Inspected subsectors & Compliant level (\%) & Non-compliant level (\%) & Total (\%) \\
\hline Subsector A & 83.05 & 16.95 & 100 \\
\hline Subsector B & 43.86 & 56.14 & 100 \\
\hline Subsector C & 76.92 & 23.08 & 100 \\
\hline Subsector D & 58.62 & 41.38 & 100 \\
\hline Subsector E & 72.50 & 27.50 & 100 \\
\hline Subsector F & 76.29 & 23.71 & 100 \\
\hline Subsector G & 67.91 & 32.09 & 100 \\
\hline Subsector H & 45.25 & 54.75 & 100 \\
\hline Subsector J & 53.60 & 46.40 & 100 \\
\hline Subsector K & 57.93 & 42.07 & 100 \\
\hline Subsector MB & 44.02 & 55.98 & 100 \\
\hline Subsector Misc \& School & 46.87 & 53.13 & 100 \\
\hline Subsector OR & 66.94 & 33.06 & 100 \\
\hline Subsector Radio & 52.18 & 47.82 & \\
\hline Note: The entire college was covered under these various subsectors & \\
\hline
\end{tabular}




\section{Compliance rates: Fire parameters}

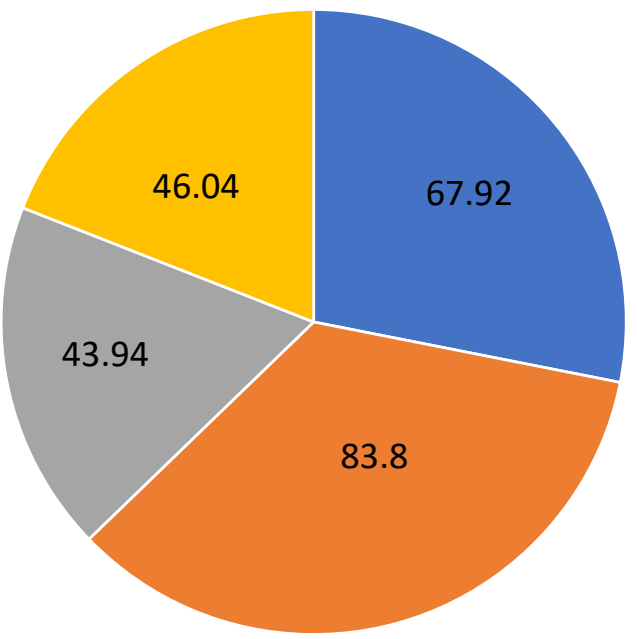

- Fire maintenance plan $\quad$ Fire prevention plan $\quad$ Staff training plan $\square$ Fire action plan

Figure II: -

\section{Subsectors compliance: Factorwise}

120

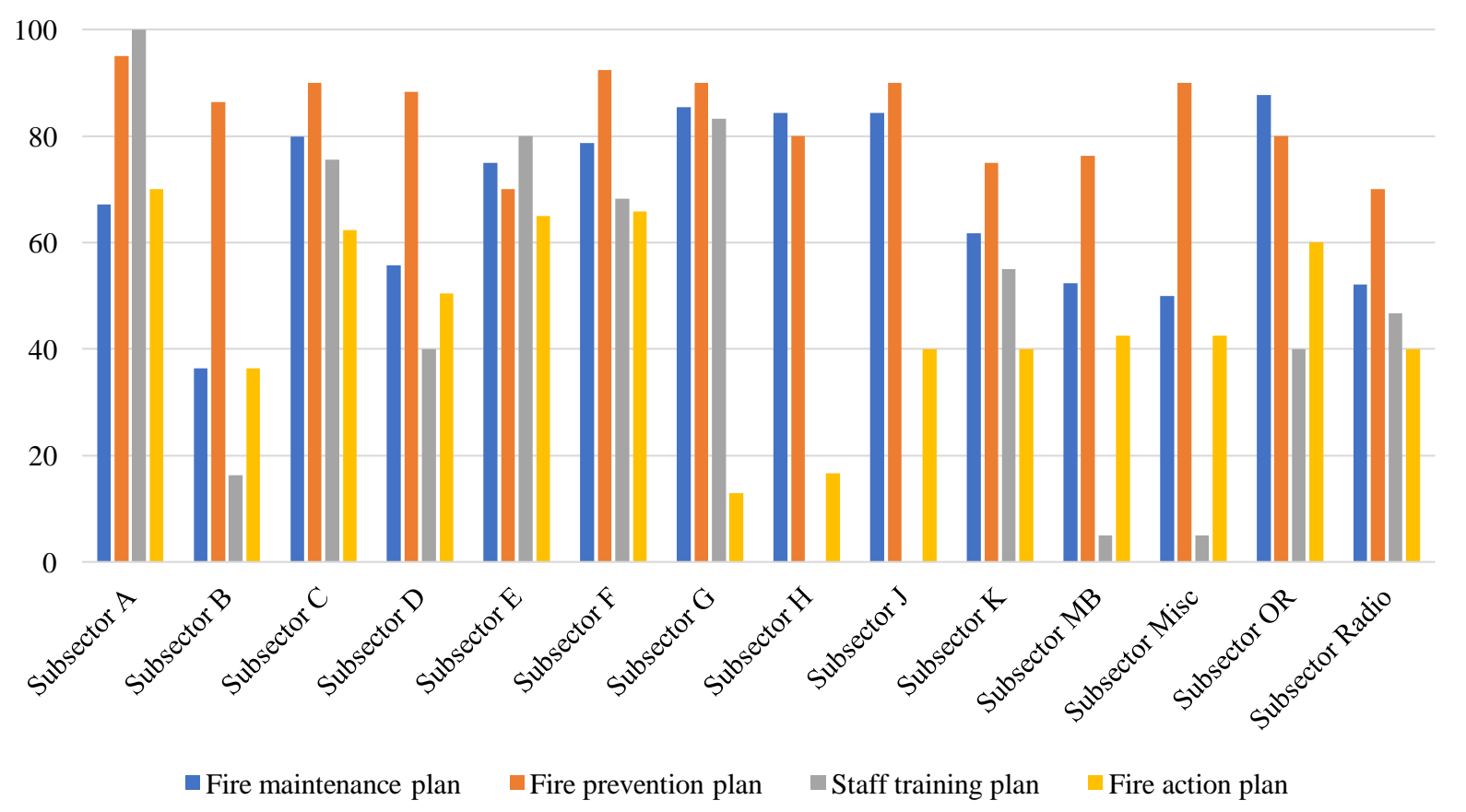

Figure III: - 


\section{Findings}

The overall fire safety compliance of the organization was found to be 60.42 percent as per the questionnaire criteria. The non-compliant factors identified were: -

1. Fire maintenance plan revealed deficiencies in firefighting equipment like noncompliance in ranking order as follows: -

1. Unavailability of safety pin

2. Pressure gauge at recharging levels

3. The firefighting equipment not fitted

4. No wall brackets, thereby critically reducing accessibility and visibility

5. Fire hose reels \& Fire hydrants not present

\section{Fire prevention plan}

1. "No smoking" signs not present

2. The electrical discipline was not maintained in various subsectors

\section{Staff Training Plan}

1. Staff training not carried out regularly

2. Staff awareness was not up-to-date

3. Mock drills were not conducted regularly

4. Records were not maintained properly

\section{Fire Alarm systems}

No building had any fire detection devices or central alarm system to alert the occupants in case of fire accident.

\section{Fire Evacuation Plan}

1. None of the standalone buildings or floors had escape plans/exit signs

2. The fire exit plan/layout was not displayed thereby leaving the occupants/visitors to guess the exit in case of any emergency

3. The exit routes were obstructed by items and furniture

4. Buildings did not have earmarked assembly area

\section{Limitations}

The findings of study are subject to few limitations. Firstly, the parameters covered may not be exhaustive and other factors may be required to be included in other organizations, depending on local circumstances. Secondly, respondents answered questions based on their perceptions, experiences and understanding. Thirdly, considering the wide spread of the organization over 107 acres, only high-risk areas were physically inspected in detail.

\section{Discussion: -}

Fire is a complex phenomenon, which characteristically occurs when there is an optimum mix of heat, fuel and oxidizing agent where fuel is the combustible agent and oxygen generally the oxidizing agent. So, the first step in fire prevention is segregating these three elements of fire triangle. The second broad step to ensure fire safety is designing buildings with fire safety parameters. Establishing fire detecting systems and fixing firefighting appurtenances in the building is the next step. But fire prevention does not stop at establishing these systems and there is a need to continuous assessment, monitoring, and improving them. Further, although the broad principles of fire prevention and response maybe same, many aspects and responses need to be customized in each building and organization depending upon the variables.

Number of variables are responsible in the fire phenomenon of the buildings, which are to be identified, assessed as fire hazard. Type of building, the activities going inside of the building, maintenance of the building, fire risk management, security management, preparedness, awareness of fire, keeping away the fire sources from the combustible materials, proper elimination of combustible materials. If we adopt these parameters in the buildings, we can avoid the fire accidents and assure the absolute safety of the buildings in future. ${ }^{[8]}$ 
Teaching institutions with residential buildings, have to comply with the fire safety guidelines of National Building Code (NBC) 2016. Preventive architectural design, fire drills, training of the hospital staff is mandatory in hospitals in western world. ${ }^{[9]}$

The study enhances understanding of dimension that fire safety management procedures must be properly implemented. The majority of the non-compliant areas involved training of the staff and fire alarm systems. Emphasis must be given on staff training and fire action plan activities. Sensitization of staff is necessary by reiterating the tragedies that a fire can bring to human life and damage to the property. The knowledge about fire safety will enable them to understand the characteristics of fire, components of fire, and the correct response in case of fire incident. Adequate training can reduce the damaging consequences of fire. Fire training needs to be conducted continuously in order to review, revise and reconfigure the knowledge. A large part of knowledge, if not used or reiterated can easily be forgotten or ignored.

The ability to elicit fire response may not only control the spread of fire, thereby giving those precious few moments, but also reduces fire damage to a lower level than would have been the case if the fire had spread unchecked. It is therefore very important that all personnel are familiar with the available fire-fighting equipment and their correct use. When fire safety information is conveyed frequently or repetitively then it becomes a habit amongst the occupants.

As part of recommendations, proper fire detection systems, fire exit plans, fire hydrants, first aid hose reel and automatic sprinkler systems in all multistoried buildings were suggested to management. The requirement of regular and periodic training and audits was also emphasized.

\section{Conclusion: -}

In the wake of growing fire incidents, it is always a good idea to review your fire prevention plans and make sure that staff are taking all necessary precautions to keep fires at bay. Required maintenance of electrical systems and equipment should be done regularly. In addition, staff members should receive regular reminders about the evacuation protocols to be followed in case of fire. ${ }^{[10]}$ Fire safety inspections with qualitative assessment by using national norms will make the management of any organization to appreciate the need for fire safety measures and treat recommendations with respect. Practically, however, society can neither forestall all loss of life nor spend limitlessly to avert loss of life due to fire. The ideal goal of life /fire safety design is to prevent all fire deaths, injuries and losses under all imaginable circumstances. History has proven that nearly every fire extinguisher failure can be traced back to human negligence.

\section{Funding}

Nil

\section{Conflicts of Interest}

There are no conflicts of interest.

\section{Acknowledgements: -}

1. I would like to pay special thankfulness, warmth and appreciation to the persons below who made this research successful and are assisting me at every point to cherish my goal.

2. My Assoc Prof, Dr Saroj Kumar Patnaik, whose help and sympathetic attitude at every point during my research helped me to work in time.

3. My Prof, Dr Surekha Kashyap for her ongoing vital support and assistance throughout the residency.

4. My Prof \& HoD of Hosp Adm, Dr Ashutosh Sharma whose kind \& able guidance and constant motivation encouraged me to meet the deadlines.

5. All the faculty and dear residents of my Dept of Hosp Adm whose compliments turned my research a success.

6. My Mother Smt Prabha Deshmukh, wife Sonali and kids Abha \& Gurudatta, without whom I am nothing. They not only assisted me morally and emotionally but also stood like a rock by me. My brother Dr Om Deshmukh for his intellectual \& technical support.

\section{References: -}

1. National fire protection association, NFPA 101, The life safety code (2009 ed) NFPA Quincy, MA, 2009 
2. National Building code, 2016 Part IV. Bureau of Indian Standards

3. Training RRC. NEBOSH International General Certificate Fire Hazards and Control NEBOSH International General Certificate Element 5 |Fire Hazards and Control Learning Outcomes. :1-38.

4. Assessment of fire prevention and protection measures in Group C buildings of Dehradun City. International Journal on occupational health, safety, fire and environment - Allied Science.

5. Chow W. Review on fire safety management and application to Hongkong. 2017;(May 2001)

6. Subramaniam C. Human factors influencing fire safety measures. 2006.

7. Zamanian Z, Evazian M, Hazeghi I, Daneshmandi H. Fire Safety Status in the Hospitals of Shiraz University of Medical Sciences, Shiraz, Iran. 2013;5(3):96-100.

8. Murali P Grace Lilly, Vijayalakshmi MM, Fire accident in building- a case Study; International J of Engineering trends and Technology 2014; 11 (May);4:178-183.

9. Srivastava P, Verma S, Fire accidents in Indian hospitals - causes and ways to prevent it.

10. White Jess, Fires in hospitals: Keys to avoid injuries \& property loss; Healthcare business and technology enewsletter; 2 Dec 2016.

11. NFSC Home [Internet]. [cited 2019 Apr 2]. Available from: https://nfsc.org/ National fire safety council guide.

12. Relevant Indian Government Acts and Rules

13. UL FSRI - Fire Safety Research Institute - Home [Internet]. [cited 2019 Apr 2]. Available from: https://ulfirefightersafety.org/JournalsPress report. 